\title{
THE EFFECT OF EXPERIENTIAL MARKETING AND PSYCHOLOGICAL PRICING ON REPURCHASE INTENTION OF CUSTOMERS IN STORE X
}

\author{
Poetri Marsya Oktriana \\ Department of Industrial and Organizational Psychology, Faculty of Psychology, \\ University of Airlangga, Surabaya, Indonesia \\ *E-mail: marsya.acha@gmail.com
}

\begin{abstract}
Increasingly sophisticated technology makes it easy for consumers to find everything they are looking for in a short time. The increasing competition requires marketers to have new marketing methods that are different from competitors. Experiential marketing is a topic that has been widely discussed by marketers to attract consumer's attention. Schmitt (1999) explains that experiential marketing is a marketing and management method that is driven by the experience of consumers. Consumers who feel great experiences when purchase, will produce customer satisfaction and loyalty so that it will form consumer repurchase intentions. Pride \& Ferrel (Ahmed \& Baruah, 2017) said psychological pricing is determined to influence consumer emotions in making decisions related to purchasing. Farisya's research (2012) shows that there is an influence of experiential marketing on repurchase intentions. However, there are still few studies that discuss the effect of psychological pricing on the repurchase intention variable. This study aims to examine the effect of experiential marketing and psychological pricing on repurchase intentions. This research was conducted on consumers who have made purchases at store X, the number of participants was 72 people. This study uses an experiential marketing scale (Schmitt, 1999), repurchase intention scale (adapted Farisya, 2012) and psychological pricing scale compiled by researchers based on Larson's theory (2014).
\end{abstract}

\section{KEY WORDS}

Experiential marketing, psychological pricing, repurchase intention, marketing.

The world industry is currently entering the era of the industrial revolution 4.0 which makes it easy for consumers to meet their needs. Increasingly sophisticated technology makes it easy for consumers to find everything they are looking for in a short time. However, this is different from the marketer's point of view. Industry 4.0 is a pretty fierce condition for marketers. They are competing to market their products/services to be attractive to consumers. The increasing competition requires marketers to have new marketing methods that are different from competitors. Ramya \& Ali (2016) said there are at least 5 (five) factors that can be influenced consumers to purchase a product/service. There are internal or psychological factors, social factors, cultural factors, economic factors, dan personal factors.

Economic factors are still the main thing for marketers to consider in setting prices and target consumers. However, Larson (2014) said that marketers today tend to use principles developed from psychology. Basically, the psychology aspect has long been used by marketers to manipulate consumer buying behavior. Experiential marketing is one of the psychological aspects developed in the field of marketing. The psychological aspect emphasized is the consumer experience, which is expected to provide satisfaction for consumers so that they have a repurchase intention. The aim is to increase sales. Andreani (2007) defines experiential marketing refers to the real experience of consumers of the brand/product/service to increase sales and brand image/brand awareness. Schmitt (1999) emphasizes the experiential marketing focuses on four things namely consumer experience, testing the situation of consumers, influencing the rational and emotional side of consumers, using electrical methods and devices to measure consumer experiences such as brands. In addition, another psychological aspect that is also under discussion in the marketing world is 
psychological pricing. Stanton (1991) mentions that there are strategies that can be used by marketers related to pricing, one of which is psychological pricing.

There are currently many shops that use experiential marketing and psychological pricing to attract consumers to purchases. The aim is to play the emotional aspects of consumers and make a significant difference with other competitor's stores. It is hoped that this will build consumer interest to repurchase so that it will provide benefits. Toko $X$ is one of the many stores that focus on shaping good experiences for consumers ranging from unique brands, comfortable places, creative products, and eye-catching packaging. In addition, store $X$ implements odd and even price which is included in psychological pricing on almost all of its products.

Some studies that examine experiential marketing associated with repurchase intentions (Farisya, 2012) explain that experiential marketing has an influence on repurchase intentions but not as much as if mediated by customer satisfaction. Ming (2010) said customer satisfaction results from experiential marketing that will lead to customer loyalty. Kotler \& Armstrong (2012) said that loyalty is a commitment or principle held by consumers to buy and support products/services that are preferred in the future. Research Ibzan, et al (2016) about Customer satisfaction and repurchase intentions shows there is a positive relationship between the two so that satisfied consumers are likely to have an interest in repurchasing compared to consumers who are dissatisfied. Asamoah \& Chovancova (2011) conducted research on the effect of price endings on consumer behavior by the application of psychological perception, the result that price endings have an influence on consumer perceptions and determine purchasing behavior. In addition, Rodhiah \& Hendrik (2008) also examined price endings (odd and even prices) on consumer perceptions. The result is that price endings have an influence in determining consumer perceptions, especially those related to prices. Kotler \& Armstrong (2012) states that price endings are one of psychological pricing. However, not many studies have examined the effect of experiential marketing and psychological pricing on repurchase intentions together.

Based on the explanation above, this study aims to examine the effect of experiential marketing and psychological pricing on the repurchase intention of customers in-store $\mathrm{X}$.

\section{LITERATURE REVIEW}

Experiential marketing is more than just giving information to consumers to gain experience on the savings obtained after using a product/service but rather to arouse the emotions and feelings of consumers that have an impact on marketing, especially sales (Andreani, 2007). Consumers can distinguish a product/service because they have experienced firsthand (Farisya, 2012). These experiences are personal events that occur due to certain stimuli provided by marketers (Schmitt, 1999). Experiential marketing will be formed one of them because of the satisfying service that is felt by consumers (Rozaqie, 2016). There are 4 (four) ways that can be done in binding consumer experience (Schmitt, 1999), namely focus on consumer experiences that can arise due to the senses, thoughts and feelings; make the situation for consumers in accordance with the state of consumers associated with the product (packaging, advertising) to create good experiences; influences not only the rational side but also the emotional side; using electrical methods and tools to measure experiences like brands. Schmitt (1999) also explains the indicators of experiential marketing: sense (creating experiences through the five senses), feel (creating experiences through feelings and emotions), think (creating experiences through thoughts), act (creating experiences through physical, interaction and lifestyle), relate (create experiences through relationships with other consumers).

Isoraite (2016) said the price is one of the most important variables of the market which will increase profits and market prices. Prices tend to be flexible and quickly adapt to changes in the environment. Kotler \& Armstrong (2012) suggested that pricing in some conditions is not in accordance with the demand and/or target marketers, so there are different pricing strategies applied by marketers. One of them is psychological pricing (Stanton, 1991). Pride \& Ferrel explained that psychological pricing is the preparation and 
presentation of the price of a product/service to stimulate emotions and influence consumers in the decision-making process (Ahmed \& Baruah, 2017). There are 4 (four) categories of principles proposed by Larson (2014) related to psychological pricing namely framing principles (buy one get one, installments, member cards); congruency principles (accuracy of prices with other consumers, perception of the price incurred with the value obtained); context principles (colour, font, size and location of prices); signalling principles (odd and even price).

Repurchase intention is defined as consumer interest which results in the purchase of the same product/service more than once (Ibzan, et al 2016). Hume, et al (2007) describes the decision of consumers to engage in future activities with marketers. If consumers are satisfied with the services provided, customer loyalty will arise so that consumer buying interest will increase and make consumers return to purchase (Anderson, 1994). Repurchase intention occurs when consumers buy back a second or more time, the reason for repurchase is mainly triggered by the consumer's experience of the product/service (Farisya, 2012).

Store $\mathrm{X}$ is a store that manufactures and sells consumer products, not just emphasizing fashion. Emphasis on function compared to style so as to reduce production costs and set prices in accordance with consumer expectations. Based on observations, store $X$ tries to provide all the needs of consumers including household appliances, beauty, stationery and so on. The arrangement is made in such a way as to make it look attractive and easy to find in stores. Store $X$ also uses lighting that is bright enough in white so that the product can look attractive so that it plays the five senses of the consumer when they arrive. Store $X$ applies the principle of odd prices, using odd numbers at suffixes such as 99 .

\section{CONCEPTUAL FRAMEWORK}

Based on the explanation of several theories previously described, this study aims to examine the effect of experiential marketing and psychological pricing on the repurchase intention of customers in-store X. Research conducted by Farisya (2012) found that there was an influence between experiential marketing on repurchase intentions. The effect increases when customer satisfaction becomes the intermediary between the two (mediator variables). Asamoah \& Chovancova (2011) conducted research on the effect of price endings on consumer behavior by the application of psychological perception, the result that price endings have an influence on consumer perceptions and determine purchasing behavior. The hypotheses in this study are:

$\mathrm{H} 1$ : There is an influence between experiential marketing $(\mathrm{X} 1)$ on repurchase intention ( $Y$ ) on store $\mathrm{X}$ consumers;

$\mathrm{H} 2$ : There is an influence between psychological pricing (X2) on repurchase intention (Y) on consumer $\mathrm{X}$ stores;

H3: There is a greater influence between experiential marketing (X1) and psychological pricing $(\mathrm{X} 2)$ on repurchase intention $(\mathrm{Y})$ on store consumers $\mathrm{X}$.

\section{METHODS OF RESEARCH}

Participants in this study are people who have purchased in-store $X$ at least once. The result was 72 stores $X$ consumers who participated in this study of various ages and genders in Indonesia. The age range obtained is $17-38$ years. Based on gender, as many as $16.7 \%$ of participants were male and $83.3 \%$ of participants were female from the total participants.

Experiential marketing and repurchase intention are measured using a scale adapted from Farisya (2012) and adjusted to where researchers conduct research. Experiential marketing consists of 14 items and repurchase intention consists of 5 items. Psychological pricing is measured using a scale created by researchers and refers to the theory of Larson (2014) with 9 items based on 4 dimensions. 


\section{RESULTS OF STUDY}

Data analysis in this study uses simple linear regression test techniques and multiple linear regression tests. Before conducting a regression analysis, the researcher first conducts several tests as a requirement for conducting multiple regression tests such as linearity test, normality test, heteroskedasticity test, and multicollinearity test. After that researchers conducted a correlation test first by using Pearson bivariate correlation analysis. The results are as follows:

Table 1 - Correlation Test Statistical Results

\begin{tabular}{|c|c|c|c|c|}
\hline No & Variable & 1 & 2 & 3 \\
\hline 1. & Experiential Marketing (X1) & 1 & 0.518 & 0.530 \\
\hline 2. & Psychological Pricing (X2) & 0.518 & 1 & 0.514 \\
\hline 3. & Repurchase Intention (Y) & 0.530 & 0.514 & 1 \\
\hline
\end{tabular}

Based on the results of the correlation test, the three correlation results in this study are classified as significant with a significance value of less than 0.05 which is equal to 0.00 at a significance level of $5 \%$. The strength of the relationship between the three variables is high. The experiential marketing variable with psychological pricing is 0.518 . The relationship between experiential marketing with repurchase intention was 0.530 and the relationship between psychological pricing and repurchase intention was 0.514 . The correlation value of the three variables shows a positive relationship so that if experiential marketing increases, psychological pricing, and repurchase intention will also increase. Similarly, if psychological pricing increases, experiential marketing, and repurchase intention will also increase. The multiple regression analysis tests conducted in this study provides the following results:

Table 2 - Statistical Results of Multiple Regression Test

\begin{tabular}{|c|c|c|c|c|c|c|}
\hline No & Regression Model & R Square & Value B & Beta & Significance & Information \\
\hline 1. & Regresi X1 ke Y & 0.281 & 0.294 & 0.530 & 0.000 & Signifikan \\
\hline 2. & Regresi X2 ke Y & 0.265 & 0.452 & 0.514 & 0.000 & Signifikan \\
\hline \multirow{2}{*}{ 3. } & \multirow{2}{*}{ Regresi X1 dan X2 ke Y } & \multirow{2}{*}{0.360} & $0.200(\mathrm{X} 1)$ & $0.360(\mathrm{X} 1)$ & $0.002(\mathrm{X} 1)$ & Signifikan \\
& & $0.288(\mathrm{X} 2)$ & $0.328(\mathrm{X} 2)$ & $0.005(\mathrm{X} 2)$ & Signifikan \\
\hline
\end{tabular}

After conducting the correlation test, researchers conducted a simple linear regression test and multiple linear regression. Based on table 2 above, it is known that the results of simple linear regression analysis and multiple linear regression analyses are met with significant values. The results of multiple linear regression tests indicate that experiential marketing and psychological pricing together affect repurchase intentions by $36 \%$. This amount is greater than the effect of experiential marketing or psychological pricing on each repurchase intention.

\section{DISCUSSION OF RESULTS}

This study aims to determine the effect of experiential marketing and psychological pricing on repurchase intentions on consumers who have made purchases in-store $X$. The results of statistical tests using multiple linear regression analysis indicate that there is an influence between experiential marketing and psychological pricing on repurchase intentions in-store $X$ consumers. Based on the statistical results obtained, the three hypotheses made by the researcher are accepted. There is an influence between experiential marketing with repurchase intention by $28.1 \%$ and between psychological pricing and repurchase intention by $26.5 \%$. These results are in line with Farisya (2014) that there is an influence between experiential marketing and repurchase intention even though the effect is not too large because it is not mediated by customer satisfaction.

However, the two percentages are not as big as the effect obtained simultaneously between experiential marketing and psychological pricing on repurchase intentions by $36 \%$. 
This is in line with Pride \& Ferrel which explains that psychological pricing is the preparation and presentation of a price of a product/service to stimulate emotions and influence consumers (Ahmed \& Baruah, 2017). This means that currently, experiential marketing is not the only variable used to influence consumer emotions. The value $36 \%$ is not a large amount to influence the repurchase intention variable. This percentage means that $36 \%$ repurchase intention is influenced by experiential marketing and psychological pricing simultaneously, while the other $64 \%$ is the influence of other variables not examined by researchers. Therefore, it is necessary to dig deeper into other variables that may be greater in influencing repurchase intentions.

\section{CONCLUSION}

Based on the results of this research, it can be concluded that experiential marketing and psychological pricing have an influence on repurchase intentions in store $\mathrm{X}$ consumers. Psychological factors such as sense, feel, think to relate and psychological prices simultaneously gradually affect the interests of store $X$ consumers in doing repurchase. Currently, the discussion about consumer psychological things still exists and continues to grow because it is proven to have an influence on consumer behavior. Given the limitations of generalization in this study, further research is expected to replicate more diverse samples in places that have different characteristics. Future studies are also expected to consider other variables that have a greater effect on the repurchase intention variable.

\section{REFERENCES}

1. Ahmed, S. \& Baruah, N.B. (2017). A Study of Perception On Psychological Pricing. EPRA International Journal of Economic and Business Review, 5(9), 194-200.

2. Anderson, E.W. \& Sullivan, M.W. (1994). The Antecedents and Consequences of Customer Satisfaction for Firms. Marketing Science 12.

3. Andreani, F. (2007). Experiential Marketing. Sebuah Pendekatan Pemasaran.Jurnal Manajemen Pemasaran, 2(1), 1-8.

4. Asamoah, E.S. \& Chovancova, M. (2011). The Influence of Price Endings on Consumer Behavior: An Application of The Psychology of Perception. Acta Universitatis Agriculturae Et Silviculturae Mendelianae Brunensis, LIX (7), 29-38.

5. Farisya. (2012). "Pengaruh Experiential Marketing Terhadap Repurchase Intention Melalui Customer Satisfaction Sebagai Intervening Variabel- Studi pada Nanny's Pavillion Bathroom Pacific Place". Universitas Indonesia.

6. Ibzan, E., Balarabe, F., Jakada, B. (2016). Consumer Satisfaction and Repurchase Intentions. Developing Country Studies, 6(2), 96-100.

7. Kotler, P. \& Amstrong, G. (2012). Principles of Marketing. New Jersey: Prentice-Hall.

8. Larson, R.B. (2014). Psychological Pricing Principles For Organizations With Market Power. Journal of Applied Business and Economics, 16(1), 11-25.

9. Ming, Chou You. (2010) "The Study of Repurchase Intention in Experiential MarketingAn Empirical Study of The Franchise Restaurant" National Kaohsiung Hospitality College, Departement of Hospitality Marketing Management

10. Ramya, N. \& Ali, S.M. (2016) Factors Affecting Consumer Behavior. International Journal of Applied Research, 2(10), 76-80.

11. Rodhiah \% Hendrik. (2008). Persepsi Konsumen Terhadap Perbedaan Odd prices Dengan Even Prices Studi Pada Mahasiswa Fakultas Ekonomi Universitas Tarumanagara Jakarta. Jurnal Manajemen, 3, 269-281.

12. Rozaqie, N., Suharyono, Kusumawati, A. (2016). Analisis Faktor-Faktor Experiential Marketing Dan Pengaruhnya Terhadap Loyalitas Pelanggan. Jurnal Administrasi Bisnis, 38(1), 30-39.

13. Schmitt, Bernd H. (1999). Experiential Marketing: How To Get Customer To Sense, Feel, Think, Act and Relate, New York: The Free Press.

14. Stanton, W.J. (1991). Fundamental of Marketing. Tokyo: Mc-Graw Hill. 